
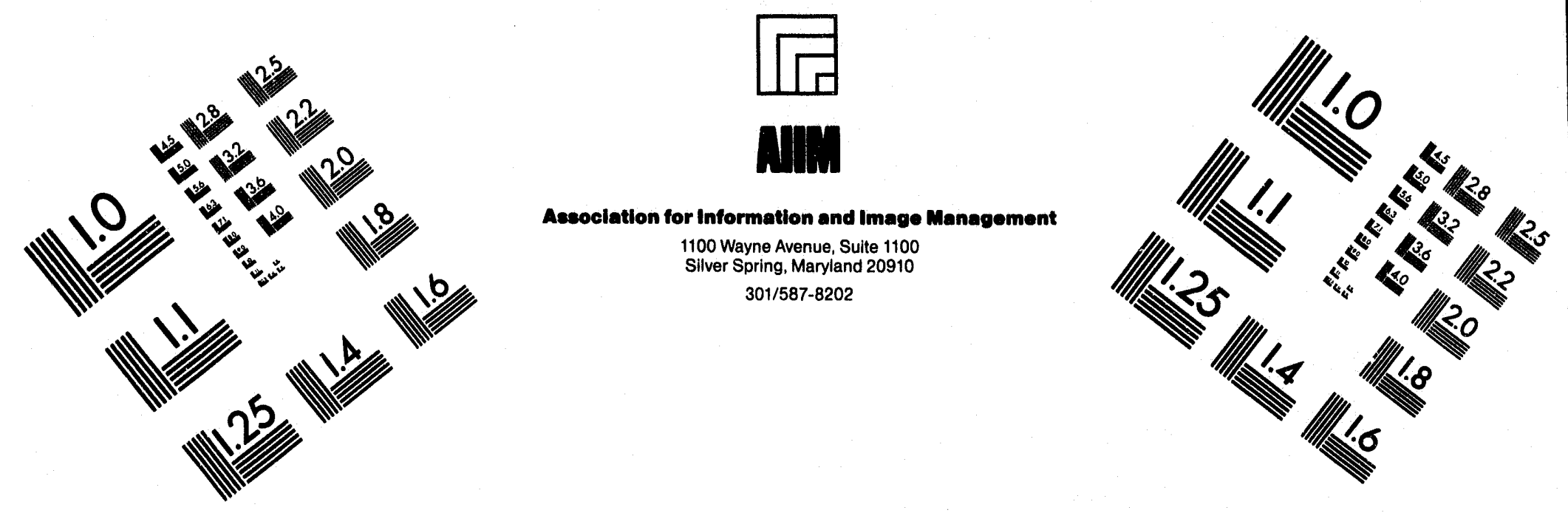

\title{
Centimeter
}

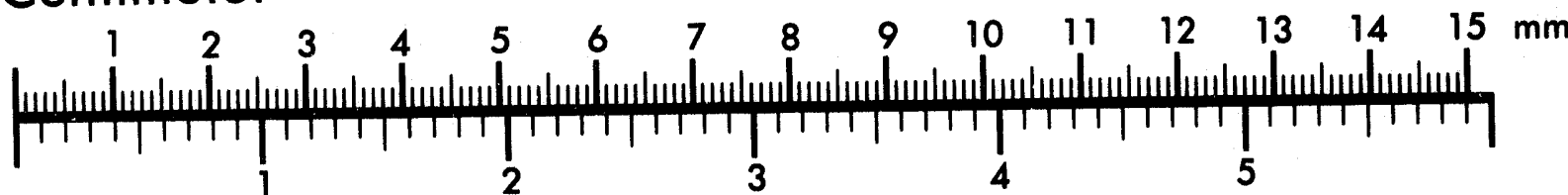

Inches
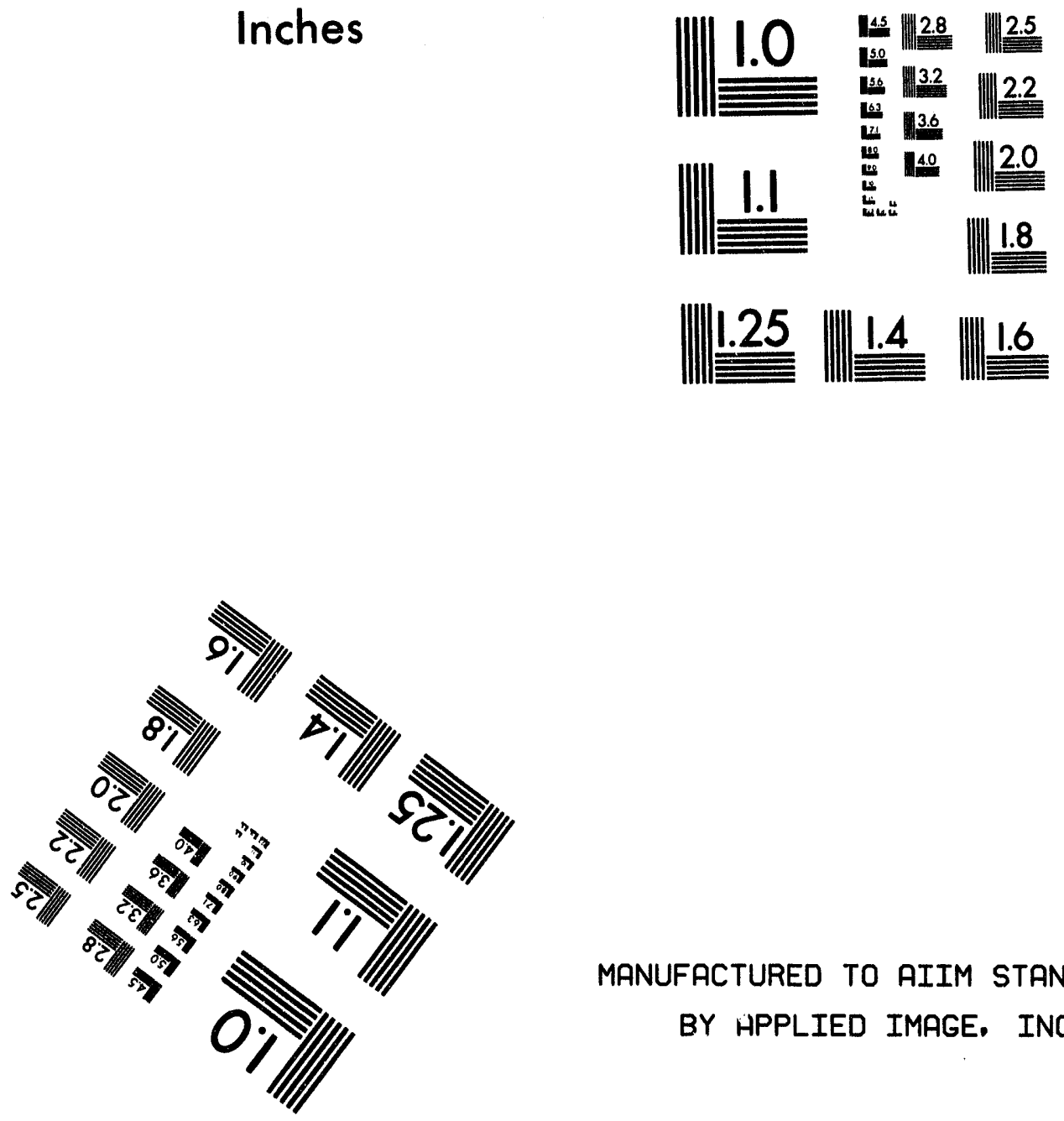

MANUFACTURED TO AIIM STANDARDS

BY HPPLIED IMAGE, INC.

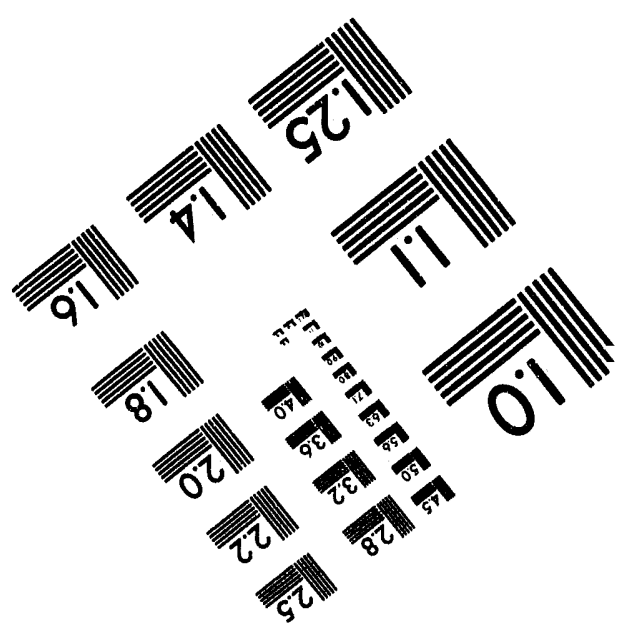



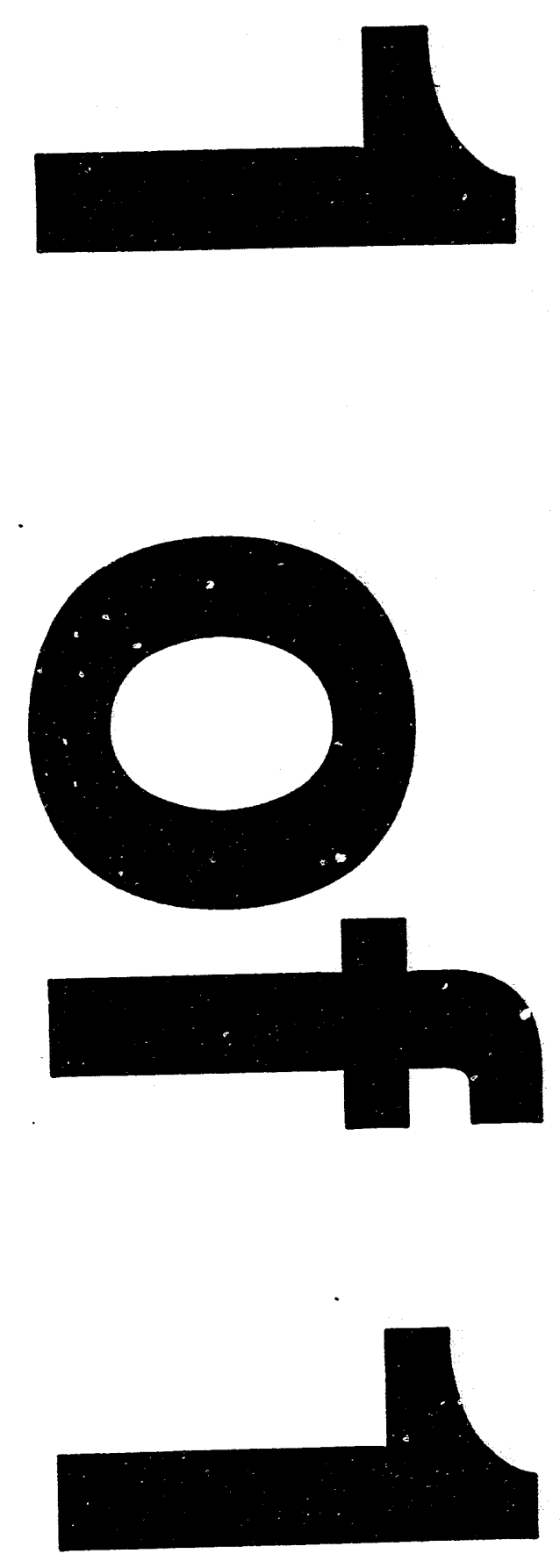


\title{
DOE Lockout/Tagout Safety Handbook
}

\author{
Bill Ulm
}

September 1993

U.S. Department of Energy

Office of the Assistant Secretary

for Environment, Safety, and Health

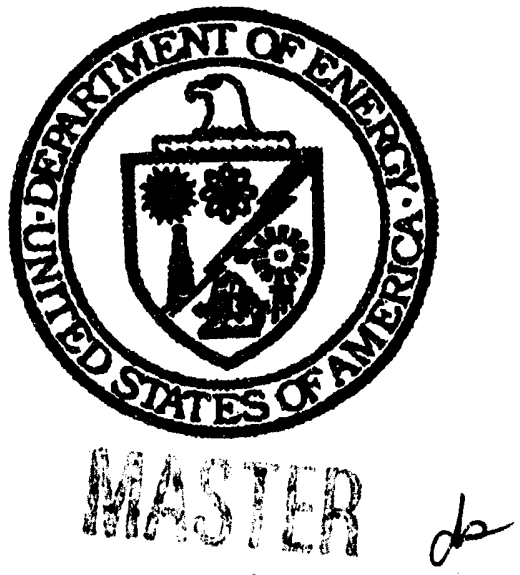


This doewnewt wasprepared as as account of work epowored by an agency sf the Unitted Statea Govemment.

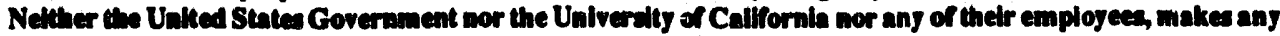
warranty, expres of baplied, or nowmen any lepal liability or respondbility for the sceuracy, completeneas, or unenulacen of any informadion, apparatus, product, or process disclosed, or represents that Its use would not

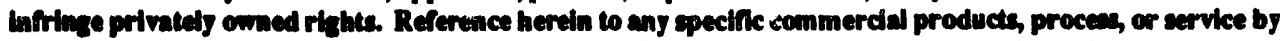
trade name, trademart, manufactures, or otherwibe, does not necesurilly constitute or imply its endorsement, recommendation, or favoring by the Unilted States Government or the Univerdity of Callfornia. The views and

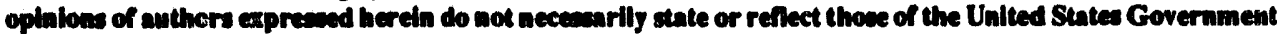
or the Unlveratty of Calffornia, and shall not be used for advertialne or product endorsoneat purpoces. 


\section{DOE Lockout/Tagout Safety Handbook}

\section{Contents}

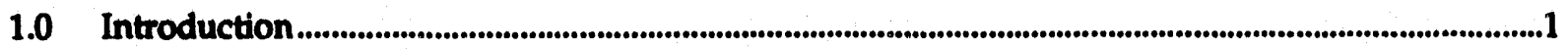

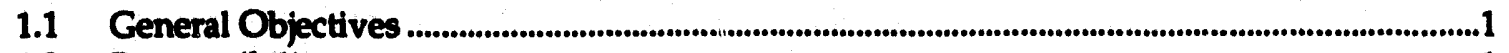

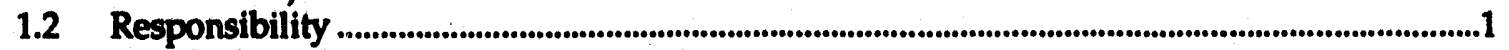

1.3 Terminology Used ........................................................................................................................1

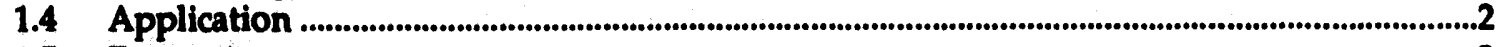

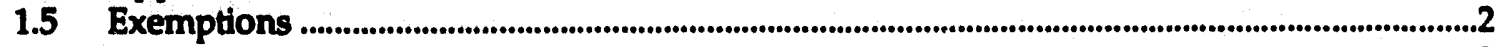

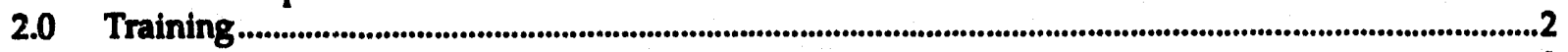

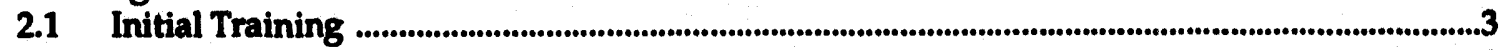

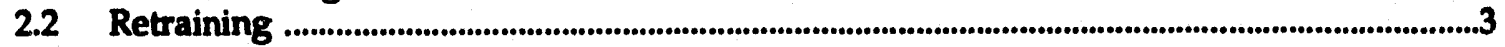

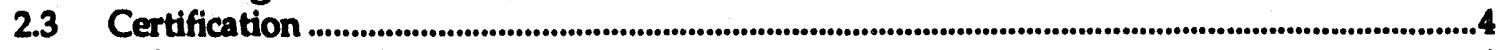

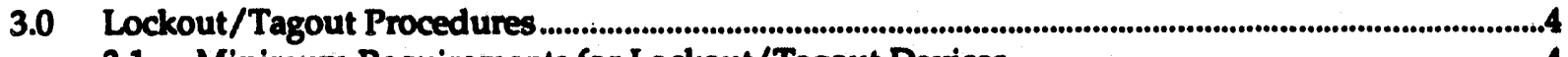

3.1 Minimum Requirements for Lockout/Tagout Devices .......................................................................4

3.2 Selection/Procurement of Protective Devices and Hardware ........................................................4

3.3 Authorized Employee Listing .........................................................................................................................4

3.4 Energy Source Survey ..............................................................................................................................4

3.5 No Lockout Provisions .....................................................................................................................................5

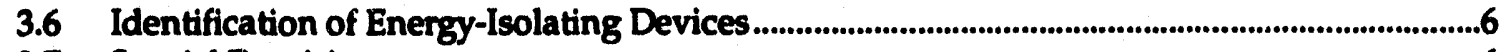

3.7 Special Provisions ...................................................................................................................................6

3.8 Lockout/Tagout Sequence ................................................................................................................7

3.9 Lockout/Tagout Application ...............................................................................................................7

3.10 Lockout/Tagout Removal ...............................................................................................................

3.11 Documentation of Lockout/Tagout..............................................................................................9

4.0 Special Lockout/Tagout Considerations ...................................................................................................................9

4.1 Interruption of Lockout/Tagout for Testing ..............................................................................9

4.2 Electrical Procedures .........................................................................................................................................9

4.3 Group Lockout/Tagout ....................................................................................................................................10

4.4 Shift/Schedule Change ...................................................................................................................................10

4.5 Outside Personnel ....................................................................................................................10

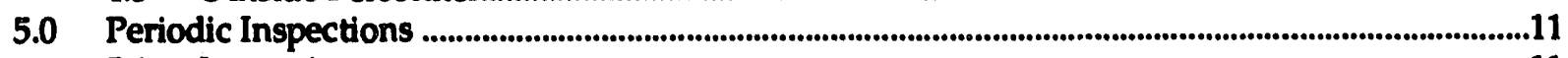

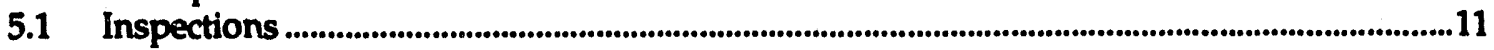

5.2 Certifications...............................................................................................................................................11

6.0 Bibliography .............................................................................................................................................................11

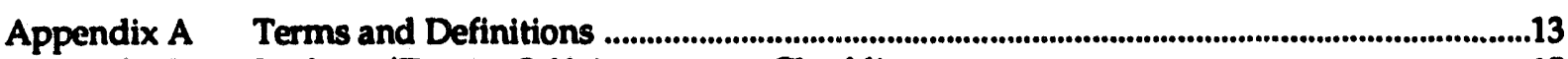

Appendix B Lockout/Tagout Self-Assessment Checklist ..................................................................................15

Appendix C Sample Lockout Procedure .......................................................................................................19

Appendix D Attachments......................................................................................................................................21

Lockout/Tagout Qualification Checklist (Attachment 1) ..................................................22

Lockout/Tagout Authorization List (Attachment 2) ..............................................................23

Lockout/Tagout Inspection Form (Attachment 3) .................................................................24

Example of Lockout/Tagout Record Sheet (Attachment 4) ..................................................25 


\section{Preface}

This lockout/tagout guide provides Department of Energy (DOE) contractors with information so that they can develop a new lockout/tagout program or modify an existing one. It also covers and expands upon information contained in the U.S. Department of Labor's Occupational Safety and Health Administration (OSHA) standards 29 CFR 1910.147, "The Control of Hazardous Energy," and 29 CFR 1910.333, "Selection and Use of Work Practices." Both of these standards are mandated by DOE Order 5483.1A, Chapter I. 1.

In addition, the guide includes a checklist to assist users in performing self-assessments of their lockout/tagout program and a sample program for use at the employee level with first-line supervisory oversight. The sample program was developed with the belief that for it to be effective at a facility, it must be understandable by all involved with its use, applied uniformly at the site, and consistently followed and enforced.

Facilities within the DOE complex may have operations that need additional or special control measures beyond those identified by OSHA. For instance, nuclear reactors, electrical utilities, and process operations with centralized control centers must have a method for controlling equipment status or may even have procedures restricting facility controls to only specially qualified individuals. These requirements not only protect employees, but also maintain the operability of crucial plant safety systems. Chapter IX, "Lockouts and Tagouts," (from Attachment I of DOE Order 5480.19) may be applicable to these facilities. DOE-STD-103092, "Guide to Good Practices for Lockouts and Tagouts," supplements Chapter DX with practices that could be applied to the special needs of these facilities.

As part of the implementation of a lockout/tagout program, each contractor must determine which guidelines are most appropriate at the facility, given the functions and organizational structure under which it operates. However, the goal of the lockout/tagout program for all DOE facilities is the same: to control potentially hazardous energy sources. 


\section{DOE Lockout/Tagout Safety Handbook}

\subsection{Introduction}

In September 1989, the Occupational Safety and Health Administration (OSHA) issued a final ruling on lockout/tagout procedures. This ruling, entitled "The Control of Hazardous Energy, (Lockout/Tagout)," became effective in January 1990 and was eventually incorporated into the Code of Federal Regulations. The purpose of these procedures is to safeguard employees from hazardous energy while performing service or maintenance activities on machines and equipment. Approximately 39 million workers are protected by lockout/tagout procedures in general industry. OSHA estimates that adherence to the requirements in lockout/tagout procedures will eliminate nearly two percent of all workplace deaths.

\subsection{General Objectives}

A lockout/tagout program is essential to the safe operation of all Department of Energy (DOE) facilities. The program outlined in this document consists of energy-control procedures, employee training, and periodic inspections, and establishes the minimum requirements for lock out/tag out of equipment or system-energy sources that could cause injury to personnel. Because serious consequences can occur due to a lack of understanding and improper administration of this program, this document also includes a method for

- Providing guidance for the control of hazardous energy.

- Protecting employees from injury.

- Defining responsibilities.

- Protecting equipment and facilities from damage.

\subsection{Responsibility}

Management is responsible for the lockout/tagout program. However, this does not alleviate employees from the responsibility of ensuring their own safety or the safety of those around them.

\subsection{Terminology Used}

- Shall-Indicates a mandatory requirement.

- Must-Also indicates a mandatory requirement; however, it is also used to express a declaration of intent, probability, or determination.

- Should-Indicates a preferred method of accomplishing an activity.

- May-Indicates an acceptable or satisfactory method of accomplishing an activity. 


\subsection{Application}

The lockout/tagout procedures in this document apply to all DOE employees and their subcontractors. They cover the control of energy sources during the service and maintenance of machines and equipment in which the unexpected start up or release of stored energy can cause injury or death to employees. These procedures also apply when employees are required to do the following:

- Remove or bypass any guard, interlock, or other safety device.

- Place any part of his/her body into an area on a machine or equipment where work is performed on the material being processed, or where an associated danger zone exists during a machine-operating cycle.

\subsection{Exemptions}

Lockout/tagout procedures do not apply to minor tool changes, adjustments, and other minor service activities that are performed during normal operations. They also do not apply to the following:

- Changes that are routine, repetitive, and integral to the use of the equipment. For example, the use of lockout/tagout procedures is not required when changing the bit on a machine lathe because this is routine activity. Bits are changed many times during a work shift and are integral to the use of the equipment. Such activities, however, must be performed using alternate measures that provide effective protection.

- Cords and plug-connected electrical equipment, if exposure to unexpected start-up are controlled by unplugging such equipment from it's energy source. The plug must also be under the exclusive control of the employee performing the service or maintenance. An example of this exemption is changing an abrasive wheels on a bench grinder.

- Hot-tap operations involving transmission and distribution systems for utilities such as water, gases, or electrical power, except if employers can demonstrate that

- Continuity of services is essential.

- Shutdown of the system is impractical.

- Documented procedures are followed, and special equipment is used that will provide proven, effective protection for employees.

\subsection{Training}

Employers must provide employees with initial training and retraining, as necessary, and must certify that such training has been provided to all employees covered in this standard. For the purposes of this document, employees who perform lockout/tagout procedures are classified as: authorized, affected, and other (see Appendix $A$ for definition). The amount and kind of training that each employee receives is based on (1) the relationship of that employee's job to the machine or equipment being locked out or tagged out, and (2) the degree of knowledge the employee must have relevant to the hazardous energy.

Authorized employees-Employees responsible for implementing the energy control procedures and for performing service and maintenance activities. At minimum, these employees are required to be provided with the details of the type and magnitude of the hazardous energy sources present in the workplace, and the methods and means necessary to isolate and control these energy sources (i.e., the elements of the energy-control procedure (s))

Affected employees-Usually machine operators or users who only need to (1) be able to recognize when control procedures are being implemented; and (2) understand the purpose of the procedures and the importance of not attempting to start up or use equipment that has been locked 
out or tagged out. These employees do not perform service or maintenance activities. Thus, under the energy-control program, affected employees shall not remove a lockout or tagout device on an energy-isolating device or shall operate the equipment.

Other employees-Individuals who may be in the area and whose responsibilities are the same as those of affected employees.

Every lockout/tagout training program must ensure that all employees understand the purpose, function, and restrictions of the energy-control program; and that authorized employees have the knowledge and skills necessary for the safe application, use, and removal of energy controls.

\subsection{Initial Training}

The following are suggested initial training and retraining for employees authorized to participate in the lockout/tagout program.

- The employee designated for lockout/tagout qualification will obtain a copy of the "Lockout/Tagout Qualification Checklist" from their supervisor (see Attachment 1 in Appendix D). The supervisor maintains a copy of this list as part of the employee's records.

- The training coordinator is contacted to schedule classroom instruction.

- Supervisors shall provide on-the-job training in all aspects of lockout/tagout, including but not be limited to the following:

- Energy-source surveys.

- Identification of energy-isolating devices.

- Lockout/tagout sequence.

- Lockout/tagout application.

- Lockout/tagout removal.

- Documentation for lockout/tagout.

- Interruption of lockout/tagout for testing.

- Group lockouts.

- Lockout/tagout inspections.

- Shift/schedule changes.

- The employee's name is added to the Lockout/Tagout "Lockout/Tagout Authorization List" (Attachment 2 in Appendix D.)

\subsection{Retraining}

Employees must be provided retraining whenever there is a change in job assignment; a change in machines, equipment, or processes that present a new hazard; or a change in energycontrol procedures. Additional retraining must be conducted when a periodic inspection indicates (or if a supervisor determines) that there are deviations from the use of the energy-control procedure and inadequacies in the employee's knowledge.

The employee's supervisor is responsible for the following:

- Ensuring that employees receive retraining.

- Reviewing the "Lockout/Tagout Av'inorization List" (Attachment 2 in Appendix D) and selecting employees affected for requalificition based on the new change.

- Completing and maintaining the qualification checklist as part of the employee's records. 


\subsection{Certification}

The department/division training coordinator shall record and maintain employees' training records. At minimum, this includes documenting the employee's name, the date lockout/tagout courses were completed, and the employee's work area.

\subsection{Lockout/Tagout Procedures}

\subsection{Minimum Requirements for Lockout/Tagout Devices}

Lockout/tagout devices used to comply with lockout/tagout procedures shall have the following characteristics:

- Durable-Devices capable of withstanding the environment to which they are exposed, for the maximum period of time that the exposure is expected.

- Unique-Devices that are distinctive, easily recognizable, and clearly visible.

- Standardized-Devices that have one or more of the following criteria: color, shape, size, or type.

- Substantial

- Locks of such durability and key-code complexity that removal by any means, other than by the regular key, would require excessive force or unusual techniques (e.g., bolt cutters). Locks will be identified for the control of energy and therefore should not be used for any other purposes (e.g., use of lockout devices for toolboxes and clothing lockers are not be permitted).

- Tags of such design that the probability of accidental removal is minimized; these tags shall have a minimum unlocking strength of no less than $50 \mathrm{lb}$, be manually attached or self-locking, and have the general design and basic characteristics of being at least equivalent to a one-piece nylon cable tie. Figure 1 shows an example of a tagout.

\subsection{Selection/Procurement of Protective Devices and Hardware}

Facilities should identify the requirements for using tags, locks, and lockout/tagout attachments and ensure that an adequate supply of these devices is maintained and distributed as needed.

\subsection{Authorized Employee Listing}

Supervisors shall maintain a listing (see Attachment 2 in Appendix D) of authorized employees who perform lockout/tagout duties in the work area.

\subsection{Energy Source Survey}

An initial survey shall be conducted to identify energy input and output sources and related exposures in equipment, systems, and machines. This survey is used to determine if adequate and appropriately located energy-isolating devices are available for protecting the worker or the equipment. Although numerous sources of energy exist, there are only two designated types: (1) primary energy, or energies that power a machine (e.g., electrical, hydraulic, and pneumatic); 
and (2) secondary energy, or energies that may be stored in a system or machine (e.g., gravity, stored mechanical energy, and residual electrical energy). See Table 3-1 for a list of hazardous energy sources.

Additionally, the potential for accidents will be reduced if employees do not rely on memory to determine which energy-isolating devices apply to which machines or to trace the equipment complexity. Inspections coupled with the use of drawings, prints, and equipment manuals will assist in the detection of system-control limitations and will be necessary for the preparation of detailed de-energization and start-up procedures.

\subsection{No Lockout Provisions}

The Occupational Safety and Health Administration has determined that lockout is a more reliable means of de-energizing equipment than tagout, and that it should always be the preferred method used by employees. With the exception of a few situations, DOE believes that the use of lockout devices will provide a more secure and effective means of protecting employees from the unexpected release of hazardous energy or the startup of machines and equipment. If an energy-isolating device is not capable of being locked out, a tagout system may be used if all three of the following provisions are met:

- It can be demonstrated that use of a tagout device will afford the same protection as a lockout.

- The tagout device is attached in the same location as the lockout.

- Additional means of protection is provided (e.g., isolating a circuit element or blocking a control switch).

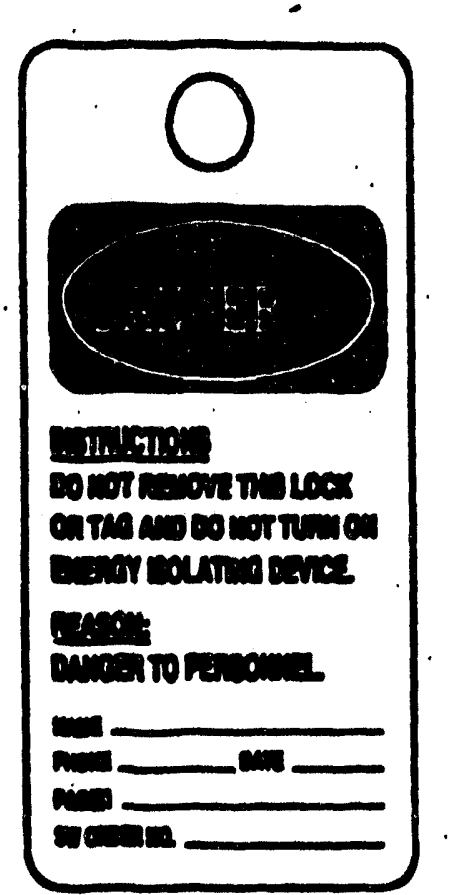

Figure 1. Tagout. 
Table 3-1. List of hazard energy sources.

\begin{tabular}{ll}
\hline Electrical Sources & Cold Sources \\
Capacitors & Cryogenic materials \\
Transformers & Ice, snow, wind, rain \\
Batteries & \\
Exposed conductors & \\
Static electricity & \\
Other high-voltage sources & \\
Motion Sources & \\
Pulley, belts, gears & Chemical Sources \\
Shears, sharp edges, pinch points & Corrosive materials \\
Vehicles & Flammable materials \\
Mass in motion & Reactive materials \\
& Pathogenic materials \\
& (virus, bacteria, etc.) \\
& Oxygen deficiency \\
Gravity-Mass Sources & Carcinogenic material \\
Falling & Heat Sources \\
Falling objects & Electrical \\
Lifting & Steam \\
Tripping, slipping & Flames \\
Earthquakes & Solar \\
& Friction \\
& Chemical reactions \\
Pressure sources & Spontaneous combustion \\
Confined gases & Radiant Sources \\
Explosives & Intense Light \\
Noise & Lasers \\
Chemical reactions & Ultraviolet \\
Stressed mechanical systems & X rays and ionizing radiation \\
& Infrared sources \\
& Electron beams \\
& Magnetic fields \\
& RF fields \\
Nuclear criticality \\
\hline
\end{tabular}

\subsection{Identification of Energy-Isolating Devices}

All energy-isolating devices must be adequately labeled or marked, except if arranged in a manner that their intended purpose is evident.

\subsection{Special Provisions}

All new or replacement equipment, or equipment and systems to which major modifications are made, shall incorporate a means to accept a lockout device. For instance, a new brake press requires lockout device', for both the electrical and hydraulic energy sources. 


\subsection{Lockout/Tagout Sequence}

Before implementation of a lockout/tagout program, affected employees shall

- Be notified of the work to be performed under lockout/tagout.

- Be informed of special operating problems, unusual equipment/process modes, and factors affecting equipment/process release.

- Have a mutual understanding with respect to the scope and time of the lockout/tagout.

Equipment complexity or other conditions may warrant the development of a special lockout/tagout procedure (see Appendix C). This plan shall include but not be limited to the following:

- Purpose and job objectives.

- Personnel responsibilities.

- Preparation for lockout.

- Sequence of lockout/tagout procedures.

- Startup provisions.

- Responsible personnel approvals.

- Procedures for more than one person.

\subsection{Lockout/Tagout Application}

Simple lockout/tagout applications (e.g., as one employee and one energy source) do not require a prepared plan; however it is advisable to have written listings of all equipment and the specific locations of their energy-isolating devices. For other situations,

1. Use the appropriate equipment shutdown procedures. An authorized employee shall turn off the operating controls. If an affected employee requires permission to gain assess to the equipment, the authorized employee will obtain that permission before shutdown begins.

2. Locate all equipment energy-isolating devices and isolate the machine from the energy source. Equipment operating controls should be in the neutral position to help in the operation of the energy-isolating devices. These devices should not be operated under load unless designed to do so.

3. Install an approved lockout/tagout device to isolate each hazardous energy source. An authorized employee shall install such devices (e.g., locks and tags) in a manner where they hold the energy-isolating device in a safe mode. If installation of the energy-isolating device inhibits attachment of the permit tag, the tag shall be positioned so that it is immediately obvious and readable to anyone attempting to operate the energy-isolating device. See Fig. 2 for lockout/tagout some methods.

4. Examine the equipment to detect and relieve any stored hazardous energy. Blocks or other physical restraints may be necessary to guarantee total immobilization of the equipment. If a possibility of energy reaccumulation exists, the machine must be relieved until there is no longer the accumulation.

5. Ensure that verification is accomplished to determine if the operation of the energyisolating device has produced the required results. For instance, operate the equipment controls or use a voltmeter to check the electrical potential.

\subsection{Lockout/Tagout Removal}

Before restoring energy to the equipment, a visual inspection and personnel count of the work area shall be made by an authorized employee. This will verify that equipment components are operationally intact and the work is complete, and that personnel are physically clear of the work area. More comprehensive measures must be taken in multiple personnel and energy-source situations. 

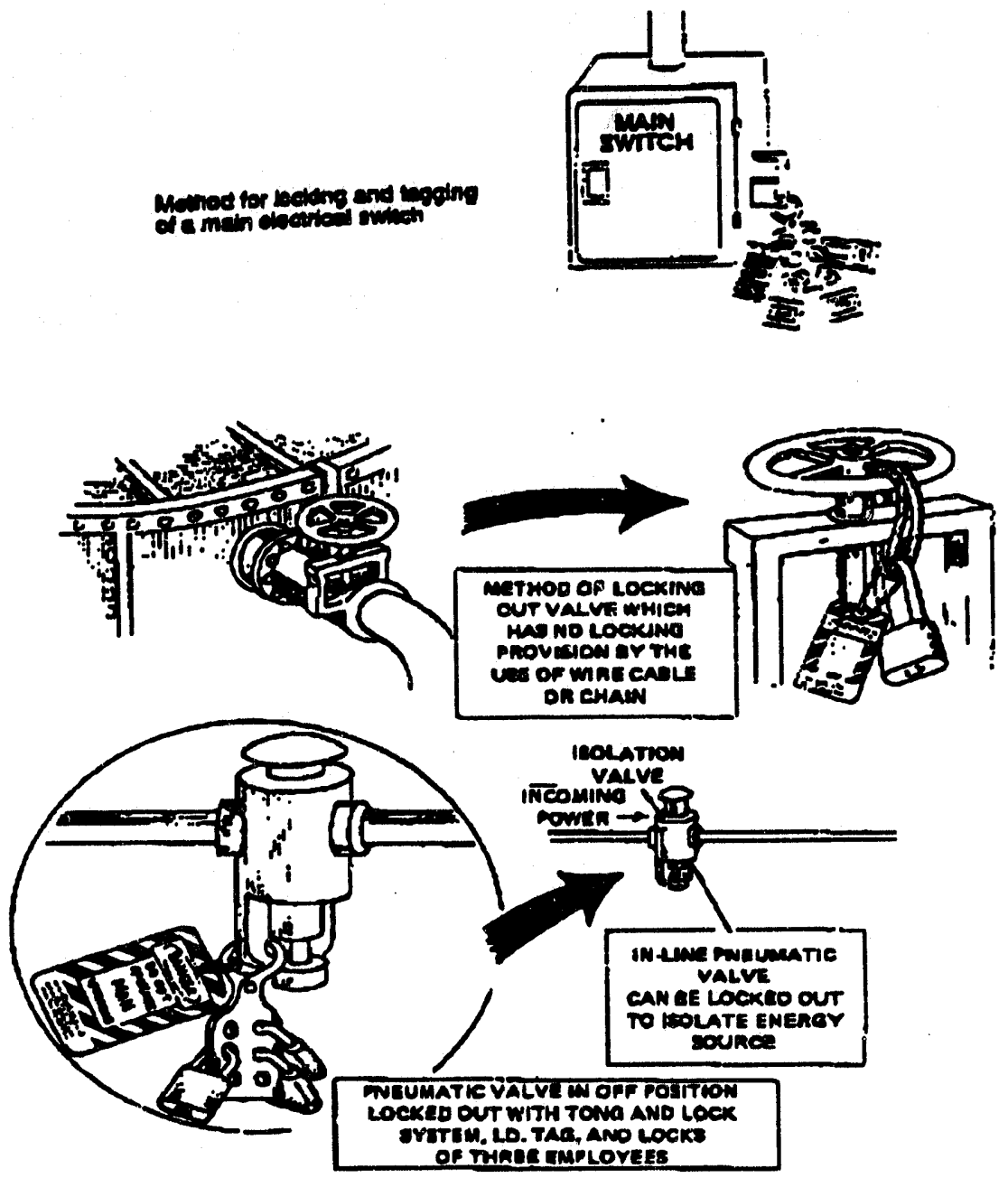

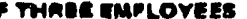

Figure 2. Lockout/tagout methods. 
Each lockout/tagout device will be removed by the authorized employee who applied it. If that employee is not available, the device may be removed under the direction of his/her supervisor provided that all of the following are completed:

- The supervisor verifies that the employee who applied the device is not at the facility.

- The supervisor makes a reasonable effort to contact the authorized employee to inform him/her that the lockout/tagout device has been removed.

- The supervisor informs the authorized employee as soon as he/she arrives at work that his/her lockout/tagout device was removed.

\subsection{Documentation of Lockout/Tagout}

Lockout/tagout placement, activation, and removal shall be recorded, including any information relevant to their occurrence. The supervisor shall maintain a record of these activities to ensure accuracy, completeness, and continuity of lockout/tagout protection. The lockout/tagout record shall be reviewed during periodic inspections. See Attachment 4 in Appendix D for an example of the "Lockout/Tagout Record Sheet."

\subsection{Special Lockout/Tagout Considerations}

\subsection{Interruption of Lockout/Tagout for Testing}

In situations where the energy-isolating devices are locked and tagged and there is a need for testing or positioning of the equipment, the following sequence must be performed:

- Clear the machine or equipment of all tools and materials.

- Ensure that all authorized and affected employees are clear of the equipment.

- Remove the lock or tag in accordance with the "Lockout/Tagout Removal" section in this document.

- Energize the equipment and proceed with testing or positioning it.

- De-energize all systems and reapply the energy-control measures upon completing the testing or positioning of the equipment.

\subsection{Electrical Procedures}

Before beginning a lockout/tagout, determine which safety procedures will be used to deenergizing the electrical circuits or equipment, then do the following:

- Disconnect all electrical circuits above $50 \mathrm{~V}$ and electrical sources before anyone works on or near them. NOTE: There are instances when authorized employees are allowed to work on energized circuits (e.g., when emergency alarms, life support equipment, lights, and/or ventilation systems will be shut down).

- Place both a lock and tag on each disconnecting means. If a lock cannot be applied, a tag must be supplemented by at least one additional safety measure (e.g., a block, an extra disconnect device, or a safety observer). A lock may be used without a tag if all the following conditions are met:

- Only one circuit or piece of equipment is de-energized.

- The lockout period does not extend into the next work shift.

- The employees exposed to the hazards associated with re-energizing the circuit or equipment are familiar with the lockout/tagout requirements of this document. 
- Release all stored energy (such as electrical energy in capacitors) before beginning work. Any stored non-electrical energy that could re-energize electrical parts must be blocked or relieved. Also, control devices such as push buttons, selector switches, and interlocks must not be used as a substitute for lockout/tagout.

- Ensure that the machinery and electrical circuits are de-energized by operating the controls and using the appropriate testing equipment. This must be done by a qualified employee.

Do the following upon completing the work:

- Remove each lock and tag. This must be done by the employee who applied them. If that employee is not available, a designated person qualified for the job may remove the lock and tag. The employee who originally applied the lock and tag must be notified that they have been removed before he/she resumes work.

- Conduct the necessary tests and visual inspections to validate that all tools, electrical jumpers, shorts, and grounds have been removed. This must be done by a qualified employee.

NOTE: If affected or other employees will be exposed to the hazards associated with reenergizing the equipment, they must be warned to stay clear of the equipment until the process is completed.

\subsection{Group Lockout/Tagout}

Some situations may require a more functional and practical method of lockout/tagout due to the scope of the job, the complexity of the equipment/system, or the number of persons involved. For example, when service and maintenance is performed as a crew, department, or other group, the lockout/tagout procedure used must afford the same protection to groups of employees as it would to a single employee. The following elements are often found in group lockout/tagout procedures:

- An authorized employee is primarily responsible for a number of personnel working under the protection of a particular lockout/tagout and for the whereabouts of all employees under his/her control. The authorized employee will apply his/her lockout to the energy-isolating device, which will remain locked out until all employees are finished working and accounted for.

- If numerous authorized and affected employees will be working on a system, a multilockout device can be used. Each authorized employee shall attach his/her own lock to the device. The system shall remain locked out until all locks have been removed.

- Whenever there is a multi-discipline group, or more than one group, an authorized employee will be designated to coordinate the group(s) and ensure the protection of all involved.

\subsection{Shift/Schedule Change}

Specific procedures should be used during personnel shift changes to ensure continuity of lockout/tagout protection, including provisions for the orderly transfer of lockout/tagout devices between personnel or shifts.

\subsection{Outside Personnel}

Established lockout/tagout procedures shall protect individuals of outside organizations (e.g., service representatives, contractor employees) from exposure due to the work they may be involved with. An authorized representative of outside organizations shall be informed of these procedures and of the need for adapting and enforcing compatible lockout/tagout protection. 


\subsection{Periodic Inspections}

\subsection{Inspections}

Periodic inspections must be performed to ensure that energy-control procedures (locks and tags) are implemented properly, and that employees are familiar with their responsibilities under those procedures. In addition, the supervisor must ensure that periodic inspections have been performed. For lockout/tagout procedure, the periodic inspection must include a review between the inspector and each authorized employee (including affected employees when reviewing tagout procedures) of that employee's responsibilities under the energy-control procedure being inspected.

The following are guidelines for lockout/tagout inspections:

- Inspections (shop level) shall be conducted at least annually. If lockout/tagout is performed frequently (more than three times a month), inspections will be conducted semi-annually.

- The inspection must be conducted by an authorized employee (someone other than the individual performing the lockout/tagout operation).

- The "Lockout/Tagout Inspection Form" (Attachment 3 in Appendix D) and the applicable questions from the "Self-Assessment Checklist" (Appendix B) may be used to perform the inspection. If discrepancies are discovered during an inspection, ensure that corrective measures are taken. For instance, if an employee is not familiar with the location of all the required energy isolation points, the corrective measures might be to retrain the individual on that aspect of lockout/tagout.

\subsection{Certifications}

The authorized inspector signs the inspection form, certifying the inspections were performed. Certification must identify the following:

- The machine or equipment on which the lockout/tagout procedure was used.

- The date of the inspection.

- The employees included in the inspection and the name of the person who performed the inspection.

- A listing of lockout/tagout discrepancies and corrective actions.

A copy of the inspections must be maintained in the employee's department until the next inspection.

\subsection{Bibliography}

U.S. Department of Labor, Occupational Safety and Health Administration (OSHA). 29 CFR 1910.147. The Control of Hazardous Energy. OSHA: Washington, DC.

Department of Energy, Manual 5480.19, Chapter 9, Lockouts and Tagouts. Washington, DC.

U.S. Department of Labor, Occupational Safety and Health Administration (OSHA). 29 CFR 1910.333. Lock and Tag Requirements for Electrical Systems. OSHA: Washington, DC. 
National Safety Council (NSC), Accident Prevention Manual for Industrial Operations. Engineering and Technology, 9th Edition, p. 396. NSC: Chicago, IL.

American National Standard Institute (ANSI) 244.1. 1982. For Personnel ProtectionLockout/Tagout of Energy Sources-Minimum Safety Requirements. ANSI: New York.

U.S. Department of Labor, Occupational Safety and Health Administration (OSHA). OSHA Handout 3120. 1991. Control of Hazardous Energy, (lockout/tagout). OSHA: Washington, DC. 


\section{Appendix A \\ Terms and Definitions}

For additional information and definitions, refer to (OSHA) 29 CFR 1910. 147, "Control of Hazardous Energy"; the American National Standard Institute (ANSI) Z244.1-1982, "Lockout/Tagout of Energy Sources"; and the Department of Energy Manual 5480.19, Chapter 9, "Lockouts and Tagouts."

Affected employee

Authorized employee

Capable of being locked out

Energized

Energy-isolating device

Energy source

Hot tap
An employee whose job requires him/her to operate or use machinery or equipment that is serviced or maintained or whose jobs require him/her to work in areas whert service or maintenance is being performed.

A person who lccks out or tags out machinery or equipment in order to perform service or maintenance on that machinery or equipment. Affected employees become authorized employees when their duties include performing service or maintenance covered under this program.

An energy-isolating device is capable of being locked out if it has a hasp or other means of attachment to which or through which a lock is affixed, or if it has a built-in locking mechanism.

Equipment or systems connected to an energy source or that contain residual or stored energy.

A mechanical device that physically prevents the transmission or release of energy. Such devices include but are not limited to a manually operated electrical circuit breaker; a disconnect switch; a manually operated switch by which the conductors of a circuit can be disconnected from all ungrounded supply conductors, a line valve, or any similar device used to block or isolate energy. (NOTE: push buttons, selector switches, and other control circuit type devices are not energy-isolating devices)

Any source of electrical, mechanical, hydraulic, pneumatic, chemical, thermal, or other energy.

A procedure used in repair, maintenance, and service activities that involves welding on a piece of equipment (i.e., pipelines, vessels, or tanks under pressure) to install connections or appurtenances. This procedure is commonly used to replace or add sections of pipeline without the interrupting service to air, gas, water, steam, and petrochemical distribution systems. 
Lockout

Lockout device

Normal production operations

Other employee

Service and/or maintenance

Setting up

Supervisor

Tagout

Tagout device
The placement of a lockout device on an ener, $y$-isolating device in accordance with established procedures to ensure that the energy-isolating device and the equipment being controlled by it cannot be operated until the lockout device is removed.

A device that uses a positive means (e.g., a key or combination lock) to hold an energy-isolating device in a safe position in order to prevent a machine or equipment from energizing. Examples of such devices included blank flanges and bolted slip blinds.

Use of a machine or equipment for its intended production function.

Employees who may be in the area where lock and tag is being performed and have a need to know. Other employees do not operate/use machinery or equipment chat is being serviced or maintained.

Workplace activities such as constructing, insta:ling, setting up, adjusting, inspecting, modifying, and maintaining and/or servicing machines or equipment. These activities also include lubricating, cleaning or unjamming machines or equipment, and making adjustments or tool changes in areas where employees may be exposed to the unexpected start up of the equipment or the release of hazardous energy.

Any work performed to prepare a machine or equipment for normal production operation.

Any person who oversees other employees and is responsible for their safety and health. Additionally, supervisors are authorized to commit manpower and equipment for the completion of a project.

The placement of a tagout device on an energy-isolating device in accordance with established procedures to indicate that the energy-isolating device and the equipment being controlled by it cannot be operated until the tagout device is removed.

A prominent warning device, such as a tag, with means of attachment that can be securely fastened to an energyisolating device. The equipment being controlled shall not be operated until the tagout device is removed. 


\section{Appendix B}

\section{Lockout/Tagout Self-Assessment Checklist}

The lockout/ tagout self assessment assists authorized employees in determining that procedures and equipment are available and that personnel are trained in the control of hazardous energy sources. This checklist only addresses the minimum required standards. Where appropriate, it may be supplemented with local site or shop-unique requirements.

\section{B.1 Training}

Yes No N/A

1. Are all authorized employees trained in the recognition of hazardous energy sources, the types and magnitude of the energy available in the workplace, and the methods and means necessary to isolate and control this energy? 29CFR 1910.147 (c)(7)(i)

2. Are affected employees instructed in the purpose and use of energy control procedures? 29CFR 1910.147 (c)(7)(i)(B)

3. Are all employees whose duties require them to be in an area where energy-control procedures are used, instructed on the procedures and restrictions relating to attempts to re-energize machines or equipment that are locked and/or tagged out? 29CFR 1910.147 (c)(7)(i)(C)

4. Are all authorized and affected employees retrained whenever there is a change in job assignments, energy-control procedures, or in equipment that presents a new hazard?

29 CFR 1910.147 (c)(7)(iii)(A)

5. Is retraining provided if lockout/tagout inspections reveal inadequacies in the employee's knowledge or in the use of the energy-control procedures?

29 CFR 1910.147 (a)(7)(iii)(B)

6. Is lockout/tagout training recorded, as a minimum, with the employee's name and class attendance date (It is recommended that these records be kept in the work area)? 29CFR 1910.147 (c)(7)(iv)

\section{B.2 Lockout/Tagout Procedures}

1. Are lockout/tagout devices capable of withstanding the environment to which they are exposed? 29CFR 1910.147 (c)(5)(ii)(A)(1) 
2. Are lockout/tagout devices easily recognizable? 29CFR 1910.147 (c)(5)(ii)

3. Do locks have substantial strength to prevent removal without applying excessive force or use of cutting tools? 29CFR 1910.147 (c)(5)(ii)(C)(1)

4. Are lockout/tagout devices standard in either shape, size, color, or format?

29CFR 191C.147 (c)(5)(ii)(B)

5. Are tags, tag attachments, and lock attachment mechanisms designed so that the probability of accidental removal is minimized?

29CFR 1910.147 (c)(5)(ii)(C)(2)

6. Are tag attachments self-locking, non-releasable, and attachable by iand? 29CFR 1910.147 (c)(5)(ii)(C)(2)

7. Have supervisors identified their requirements for tags, locks, and attachment hardware and have an adequate supply on-hand?

29CFR 1910.147 (c)(5)(i)(ii)

8. Has an initial survey been completed to identify all primary and secondary equipment energy sources? 29CFR 1910.147 (d)(1)

9. Can it be shown that a tagout affords the same level of protection as lockout because an additional safety measure is used (e.g., blocking a control) if an energy-isolating device is not capable of being locked out? 29CFR $1910.147^{\prime}$ (c)(3)(i)(ii)

10. Is there a written procedure that identifies all energy-isolated devices or shop equipment? 29CFR 1910.147 (c)(4)(i)

11. Are all energy-isolating devices adequately labeled or marked to indicate the employee who applied the device? 29CFR 1910.147 (c)(5)(ii)(D)

12. Can all new or replacement equipment accept a lock device? 29CFR 1910.147 (c)(2)(iii)

13. Are all affected employees notified of the work to be performed before lockout/tagout implementation? 29CFR 1910.147 (c)(9) 
14. Is a special lockout/tagout procedure developed If equipment complexity warrants it? 29CFR 1910.147 (c)(4)(i)

15. Do affected employees review the lockout/tagout procedure sequences for complex operations? 29CFR 1910.147 (c)(7)(i)(A)

16. Is there a written listing of all energy-isolating devices on shop equipment? 29CFR 1910.147 (c)(4)(i) (ii)

17. Are all operating controls turned off by an authorized employee during lockout/tagout? 29CFR 1910.147 (d)(1)(2)

18. Is a lock or tag used by an authorized employee to isolate each hazardous energy source? 29CFR 1910.147 (d)(4)(i)

19. Are all potentially stored or residual energy relieved, disconnected, restrained, and rendered safe after lockout or tagout devices have been applied?

29CFR 1910.147 (d)(5)(i)

20. Has the authorized employee verified that the equipment is isolated and de-energized after the equipment is locked or tagged out and before starting work on the equipment? 29CFR 1910.147 (d)(6)

21. Has a visual inspection and personnel count of the work area been conducted by an authorized employee before lockout or tagout devices are removed and energy is restored? 29CFR $1910.147(e)(1)$

22. Is each lockout/tagout device removed by the authorized employee who applied it? 29CFR 1910.147 (e)(3)

23. Does the supervisor maintain a record of placement and removal of lockouts/tagouts? 29CFR 1910.147 (c)(4)(ii)(C) 


\section{B.3 Special Lockout/Tagout Considerations}

1. Does the procedure provide the same protection that a single employee would recelve if a group lockout/tagout system exists? 29CFR 1910.147 (f)(3)(1)

2. Is responsibility for a number of personne: working under the protection of a particular lockout/tagout vested with an authorized employee? 29CFR 1910.147 (f)(3)(ii)(A)

3. Are specific lockout/tagout procedures established for use during shift change? 29CFR 1910.147 (f)(4)

4. Do our personnel ensure compliance with lockout/tagout procedures if outside contractors are working onsite? 29CFR 1910.147 (f)(2)(i)(ii)

\section{B.4 Periodic Inspections}

1. Are periodic inspections of lockout/tagout procedures conducted at least annually? 29CFR 1910.147 (c)(6)(i)

2. Are inspections conducted by an authorized employee, (i.e., someone other than the person using the lockout/ tagout procedures)? 29CFR $1910.147(c)(6)(i)(A)$

3. Does the inspection include a review between the inspector and the authorized/affected employee of his/her responsibilities under the lockout/tagout program? 29CFR 1910.147 (c)(6)(i)(D)

4. Are inspections certified and do they include the date of the inspection, the employee's and inspector's name, and the equipment on which the lockout/tagout procedure is being used?

29CFR 1910.147 (c)(6)(ii) 


\section{Appendix C \\ Sample Lockout Procedure}

Effective Dates:

to

Location

This procedure is provided as a guide for developing a specific lockout procedure; tagout procedures have a similar format. Complex lockout/tagout may require the development, documentation, and implementation of a more comprehensive procedure.

Lockout procedure for

\section{Purpose}

This procedure establishes the minimum requirements for the lockout of energy sources that can cause infury to personnel. All employees shall comply with this procedure.

\section{Responsibility}

All employees shall follow lockout/tagout procedures and shall be instructed by a designated person(s) on the safety significance of the procedure. The designated person(s) shall also inform new, transferred, or affected employees of the purpose and use of this procedure.

\section{Preparation for Lockout}

Because more than one energy source (electrical, mechanical, or others) may be involved, employees authorized to perform a lockout must be sure which switch, valve, or other energy-isolating devices apply to the equipment being locked out. Questions regarding the identification of sources should be referred to the employee's supervisor. NOTE: Job authorization should be obtained before beginning a lockout.

\section{Sequence of Lockout}

1. Notify all affected employees of a lockout and the reason(s) for the lockout.

2. Shut down the equipment if it is in operation; use the normal stopping procedure (depress the stop button; open the toggle switch).

3. Operate the switch, valve, or other energy-isolating device so that the energy source(s) (electrical, mechanical, hydraulic) is disconnected or isolated from the equipment. Stored energy (such as that in capacitors, springs, elevated machine members, rotating flywheels, hydraulic systems, and air, gas, steam, or water pressure) must also be dissipated or restrained by methods such as grounding, reposittoning, blocking, or bleeding down.

4. Lock out the energy-isolating device with an assigned individual lock. 
CAUTION: Do step 5 only after ensuring that no personnel are exposed and that the energy sources are disconnected. Return the operating controls to the neutral position after the test.

5. Activate the push button or other normal operating controls to ensure that the equipment will not operate; if electrical, test the voltage. The equipment is now locked out.

\section{Restoring Equipment to Service}

Do the following to return the equipment to service:

1. Check the equipment area to see that no one has been exposed. This should be done upon completing the job and when the equipment is ready for testing or normal service.

2. Remove all locks when the equipment is all clear. The energy-isolating devices may be operated to restore energy to the equipment.

\section{Procedures Involving More Than One Person}

If it is necessary for more than one person to lock out the equipment, each person shall place his/her own personal lock on the energy-isolating device(s). A designated person of a work crew or a supervisor with the knowledge of the crew may lock out the equipment for the whole crew. In such cases, that person is responsible for carrying out all steps of the lockout procedure and for informing the rest of crew when it is safe to work on the equipment. Additionally, the designated person shall not remove a lock until it has been verified that the other crew members are not exposed to danger.

\section{Rules for Using Lockout Procedures}

All equipment shall be locked out to protect employees from accidental or inadvertent operation, especially when such operations could cause injury. Do not attempt to operate a switch, valve, or energy-isolating device that has a lock.

\section{Approval Signatures}




\section{Appendix D}

\section{Examples/Forms}

This appendix contains the following:

- Lockout/Tagout Qualification Checklist (Attachment 1).

- Lockout/Tagout Authorization List (Attachment (2).

- Lockout/Tagout Inspection Form (Attachment 3).

- Example of Lockout/Tagout Record Sheet (Attachment 4). 


\section{Attachment 1 \\ Lockout/Tagout Qualification Checklist}

\section{Section I}

Reason for training (check one):

( ) Initial Training

(Complete sections I through III)

( ) Retraining

(Complete sections I and III)

Employee'sname

Date

Division/Group

EmployeeNo.

Signature of supervisor/Date

\section{Section II}

The candidate received formal training in lockout/tagout procedures and has successfully passed the written examination.

Signature of instructor/Date

\section{Section III}

The employee has been provided on-the-job training in the following aspects of lockout/tagout:

- Energy source surveys.

- Lockout/tagout sequence.

- Lockout/tagout application.

- Lockout/tagout removal.

- Group lockouts.

- Lockout/tagout inspections.

- Shift/schedule changes.

- Interruption of lockout/tagout for testing.

- Identification of energy-isolating devices.

Signature of supervisor/Date 


\section{Attachment 2 \\ Lockout/Tagout Authorization List}

List the personnel authorized as lockout/tagout holders.

Name

1.

2.

3.

4.

5.

6.

7.

8.

9.

10.

11.

12

13.

14.

15.

16.

17.

18.

19.

20.
Department

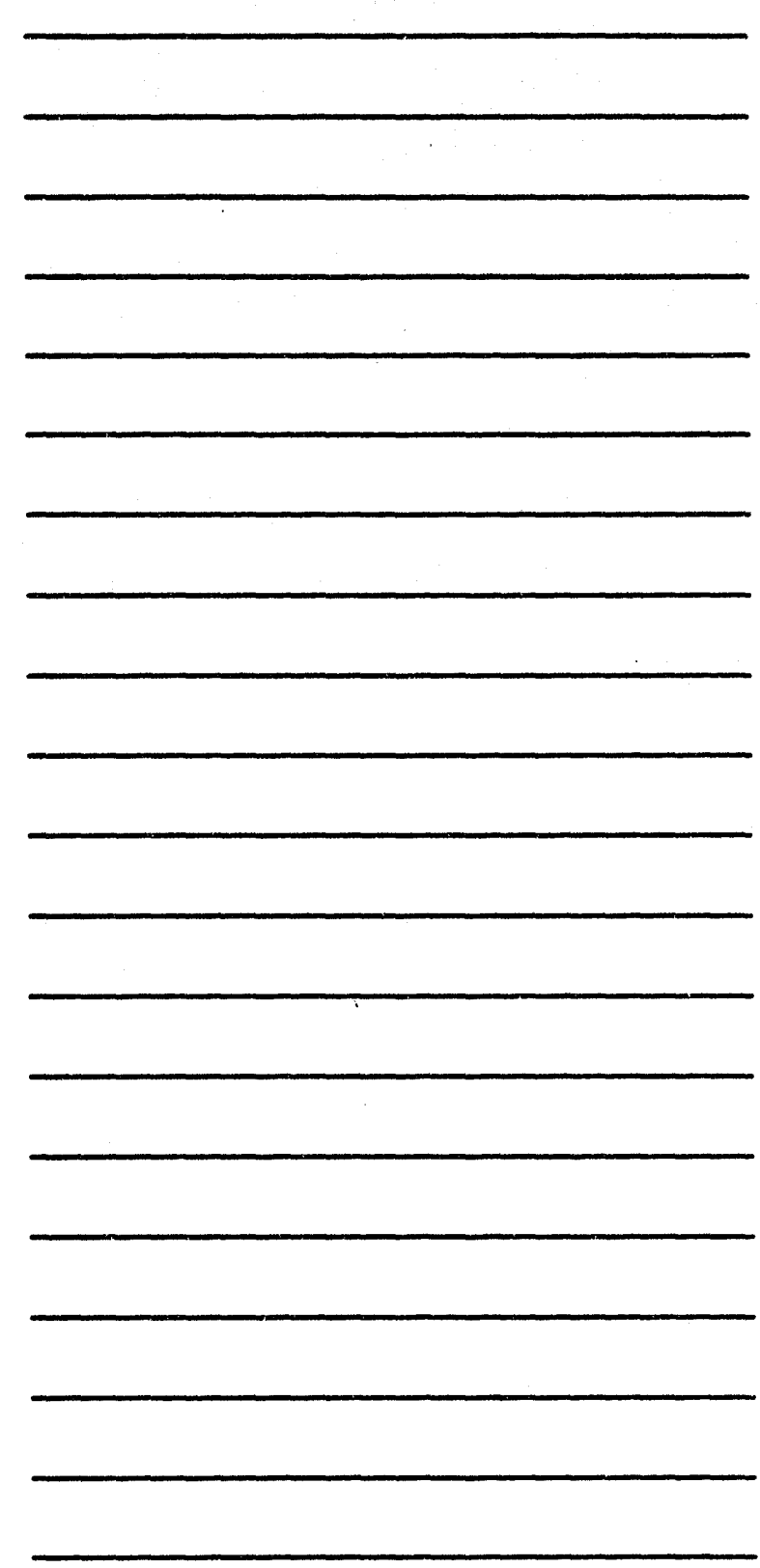




\section{Attachment 3 \\ Lockout/Tagout Inspection Form}

This form must be completed by an authorized lockout/tagout holder. (NOTE: The individual completing this form must be someone other than the employee performing the lockout/tagout operation.)

1. Dare

2. List the equipment/machines on which the energy-control procedure is being used.

3. List the names of the employees who reviewed the lockout/tagout procedures and were included in this inspection. Add the names of affected employees if this inspection is for tagout.

a.

b.

c.

d.

e.

4. Identify any discrepancies found from the "Self-Assessment Checklist" (Appendix B) and list the corrective actions. f.

$\mathbf{8}$

h

i.

j.

5.

Signature of authorized inspector/Date 


\section{Attachment 4}

\section{Example of Lockout/Tagout Record Sheet}

LockoutrTagout Boundries and Grounds

Prepared by:

Authorized person

Verified by:

Authorized person

Lockout/Tagout Number:

\begin{tabular}{|c|c|c|c|c|c|c|c|c|c|c|}
\hline \multicolumn{4}{|c|}{ Boundaries, Grounds, and Verification Points } & \multicolumn{2}{|c|}{ Lock/Tag Placement } & \multicolumn{5}{|c|}{ Lock/Tag Restoration to Operable Status } \\
\hline $\begin{array}{l}\text { Tas } \\
\text { No. }\end{array}$ & Component & $\begin{array}{l}\text { Required } \\
\text { Component } \\
\text { Position }\end{array}$ & Seq. & $\begin{array}{l}\text { Lock/Tag } \\
\text { Placed } \\
\text { (Initial) }\end{array}$ & $\begin{array}{l}\text { Lock/Tag } \\
\text { Verified } \\
\text { (Initial) }\end{array}$ & $\begin{array}{l}\text { Required } \\
\text { Component } \\
\text { Position }\end{array}$ & Seq. & $\begin{array}{l}\text { Removal } \\
\text { Authorized } \\
\text { (Initial) }\end{array}$ & $\begin{array}{c}\text { Removed } \\
\text { Restored } \\
\text { (Initial) }\end{array}$ & $\begin{array}{l}\text { Removal } \\
\text { Verified } \\
\text { (Initial) }\end{array}$ \\
\hline & & & & & & & & & & \\
\hline & & & & & & & & & & \\
\hline & & & & & & & & & & \\
\hline & & & & & & . & & & & \\
\hline & & & & & & & & & & \\
\hline & & & & & & & & & & \\
\hline & & & & & & & & & & \\
\hline & & & & & & & & & & \\
\hline & & & & & & & & & & \\
\hline & & & & & & & & & & \\
\hline
\end{tabular}

Tag list continued on additional sheets

-Yes

1

点

Remarks: 

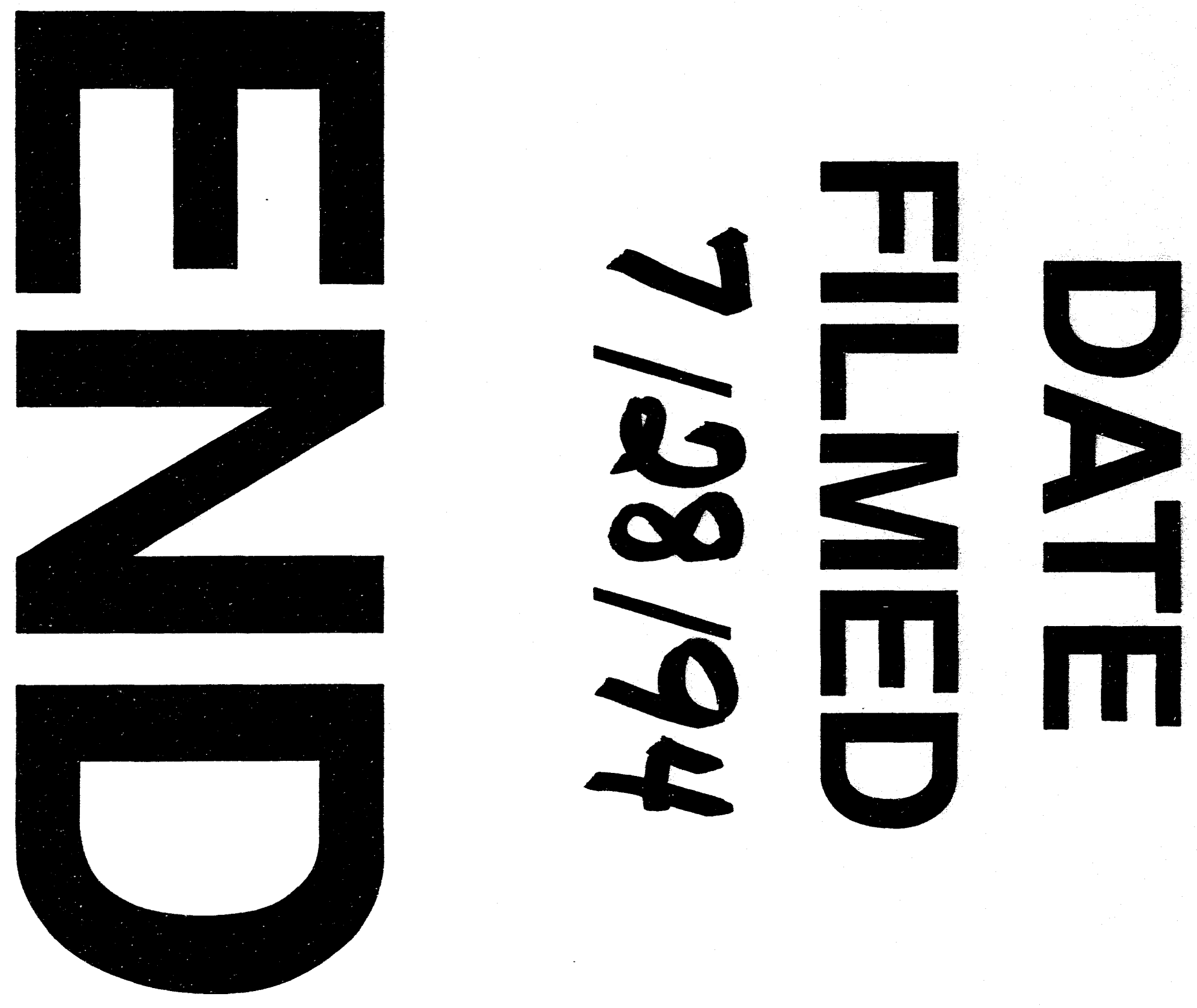


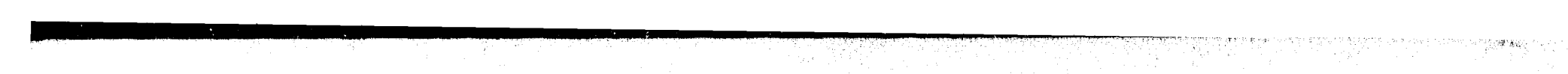

